УДК 657:339:004

\title{
СУТНІСТЬ ТА ОСОБЛИВОСТІ ОБЛІКУ ОПЕРАЦІЙ ДРОПШИПІНГУ ЯК ФОРМИ ЕЛЕКТРОННОї ТОРГІВЛІ
}

\section{ESSENCE AND FEATURES OF ACCOUNTING OF OPERATIONS DROPSHIPING AS A FORM OF E-COMMERCE}

\author{
Онищенко Оксана Володимирівна \\ кандидат економічних наук, доцент, \\ Кременчуцький національний університет \\ імені Михайла Остроградського \\ ORCID: https://orcid.org/0000-0003-3272-9755 \\ Олійник Євгенія Валеріївна \\ кандидат економічних наук, доцент, \\ Кременчуцький національний університет \\ імені Михайла Остроградського \\ ORCID: https://orcid.org/0000-0002-8943-0992 \\ Беззуб Анастасія Володимирівна \\ студентка, \\ Кременчуцький національний університет \\ імені Михайла Остроградського \\ ORCID: https://orcid.org/0000-0002-9845-1365
}

\section{Onyshchenko Oksana, Oliinyk Evgenia, Bezzub Anastasia Kremenchuk Mykhailo Ostrohradskyi National University}

\begin{abstract}
Стаття присвячена актуальним питання значення та ролі електронної комерції у світовій економіці та такої популярної онлайн-системи купівлі та продажу серед населення як системі, що використовує концепцію дропшипінгу. Досліджено основні характеристики, схему діяльності системи дропшипінгу, етапи здійснення, особливості співпраці в цій системі та законодавче оформлення. Зазначені переваги системи дропшипінгу, при цьому звертається увага і на існуючі проблеми в дропшипінгу, такі як: знайти надійного постачальника; відсутність контролю за товарними запасами, велика конкуренція, необхідність певних навичок при веденні бізнесу. Особлива увага була приділена розгляду питань облікового відображення операцій дропшипінгу, як актуальної моделі електронної торгівлі: обліковому відображенню операцій дропшипінгу з позиції дропшипера за умови агентської діяльності та в умовах укладання договорів та доручення.
\end{abstract}

Ключові слова: дропшипінг, дропшипер, бізнес модель, електронна комерція, облік, постачальники.

Статья посвящена актуальным вопрос значения и роли электронной коммерции в мировой экономике и такой популярной онлайн-системы покупки и продажи среди населения как системе, использующей концепцию дропшипингу. Исследованы основные характеристики, схема деятельности системы дропшипингу, этапы осуществления, особенности сотрудничества в этой системе и законодательное оформление. Указанные преимущества системы дропшипингу, при этом обращается внимание и на существующие проблемы в дропшипингу, такие как: найти надежного поставщика; отсутствие контроля за товарными запасами, большая конкуренция, необходимость определенных навыков при ведении бизнеса. Особое внимание было уделено рассмотрению вопросов учетной отражения операций дропшипингу, как актуальной модели электронной торговли: учетном отражению операций дропшипингу с позиции дропшипера при агентской деятельности и в условиях заключения договоров и поручения.

Ключевые слова: дропшипинг, дропшипер, бизнес модель, электронная коммерция, учет, поставщики. 
The article is devoted to topical issues of the importance and role of e-commerce in the world economy and such a popular online system of buying and selling among the population as a system that uses the concept of dropshipping. The main characteristics, the scheme of activity of the dropshipping system, stages of implementation, features of cooperation in this system and legislative registration have been investigated. The advantages of the dropshipping system are mentioned, and attention is paid to the existing problems in dropshipping, such as: finding a reliable supplier; lack of control over inventories, high competition, the need for certain skills in doing business. Particular attention was paid to the issues of accounting of dropshipping operations as an actual model of e-commerce: accounting of dropshipping operations from the position of dropshiper in terms of agency activities and in terms of concluding contracts and instructions. There are three related parties in the dropshipping system: the buyer, the seller (owners of the goods) and the dropshipper intermediary. Dropshipper for its operation has no costs for the maintenance of office, warehouse, staff, purchase of goods, so earnings through direct delivery service is more efficient than offline trade. However, some initial costs will still be, such as creating a site, advertising costs, finding customers. Despite the small costs, the final costs are sufficiently lower than in the organization of ordinary trade, which includes the search for storage space, purchase of goods and more. Based on the study, it was noted that e-business has become a modern, promising area in high demand, in which economic agents not only develop their business, but also have the opportunity to gain advanced knowledge and skills in various fields. The main conclusion of the study is that the dropshipping business model for retailers is quite new, to date there have been no large national providers providing these services, instead this system consists mainly of small businesses operating as a limited liability company. This method of implementation is quite promising in Ukraine, as dropshipper is not limited to investment, the average earnings of this activity depends primarily on proper organizational work, which includes searching for suppliers and advertising, as well as the type of goods, the city, where sales will be made, from the competitive environment, pricing policy, etc. Ultimately, this structural system is viable, although the set of elements that make it up is not yet highly professional, which corresponds to a high level of profitability of end customers.

Keywords: dropshipping, dropshipper, business model, e-commerce, accounting, suppliers.

Постановка проблеми. Сучасний глобальний маркетинг надає можливість обслуговувати клієнтів незалежно від відстані та наявності розвиненої торговельної інфрраструктури. Ця обставина докорінно змінює всю систему просування товарів і обслуговування споживачів. Відкриваючи нові можливості в освоєнні споживчих ринків навіть невеликими компаніями з обмеженими первинними ресурсами.

Один товар зараз продається на декількох веб-сайтах і споживачі можуть порівняти та вибрати, де кращі цінові пропозиції, умови купівлі. У зв'язку з загостренням конкуренції, продавці мінімізують свій прибуток та надають покупцям максимальну вигоду, Раніше продавці знали, що покупці не мають широкого доступу до потрібних їм товарів, вони можуть витрачати час та гроші на купівлю невеликої кількості речей, тому в той час продавці користувалися цим. Проте зараз, з появою електронної комерції, у клієнтів $€$ багато різноманітних варіантів виробу своєї продукції. Проблема відсутності грошей довгий час була головною біллю бізнесменів, поки не з'явилася інтернет-комерція. Завдяки їх, можна почати своє діло, максимально скоротивши витрати на просування бізнесу. Тож новий вид комерції пов'язаний з поняттям «дропшипінг». Проте внаслідок того, що це відносно новий вид підприємницької діяльності, то й розглядати його можусь із різних боків, що призводить до різних варіантів обліку. Крім того, досі зако- нодавчо не встановлено положення з обліку операцій дропшипінгу. Це обґрунтовує актуальність цього дослідження.

Аналіз останніх досліджень і публікацій. Проблеми дропшиппінгу та питання використання переваг даної фрорми співпраці піднімали у своїх працях вітчизняні та зарубіжні вчені, зокрема, Т.В. Гудзь, Є.М. Заїкін, М.Л. Калужський, Б.Є. Керничний, І.В. Припадчева, І.Б. Федишин, В. Федоричак, В.М. Ходиревська, Г.А. Яшева та ін. 3 позицій бухгалтерського обліку, в частині оформлення договірних відносин дропшиппінгу, а саме питання фрормування агентського, комісійного договору розглядали М. Шевчук, Т. Алієв. В свою чергу, питання сутності та особливостей обліку операцій дропшиппінгу досліджував А.В. Тирінов.

Виділення не вирішених раніше частин загальної проблеми. Однак, зважаючи на специфріку дропшиппінгу, переваги та багатоваріативність схем його використання, недосконалість нормативного й методичного забезпечення бухгалтерського обліку розрахунків з покупцями і замовниками актуальним $\epsilon$ вивчення облікових аспектів даної фрорми здійснення господарської діяльності, зокрема в контексті розрахунків з покупцями та замовниками.

Формулювання цілей статті (постановка завдання). Метою даної наукової роботи $\epsilon$ визначення сутності дропшипінгу, його переваг і недоліків для різних учасників, вивчення облікових аспектів та оподаткування опера- 
цій дропшипінгу враховуючи право власності дропшиперів на реалізовані ними товари кінцевим покупцям.

Виклад основного матеріалу дослідження. Велика кількість корпорацій переходять в онлайн-торгівлю через доступність та широкого охоплення клієнтів. Сьогодні кожний бізнес відчуває необхідність присутності в Інтернеті, аби підвисити впізнаваність свого бренду та охопити велику кількість клієнтів. Якщо подивитися на останні тенденції, то ринок показав великий зріст доходів компаній, котрі перевели свій бізнес в онлайн-торгівлю (рис. 1).

Інтернет надає можливість обслуговувати клієнтів незалежно від відстані та наявності розвиненої торговельної інфрраструктури. Ця обставина докорінно змінює всю систему просування товарів і обслуговування споживачів. Відкриваючи нові можливості в освоєнні споживчих ринків навіть невеликими компаніями з обмеженими первинними ресурсами.

В Україні почала активно розвиватися доставка товарів до роздрібних споживачів, якою займається не продавець, а безпосередньо посередник-дропшипер. Таким чином знижуються витрати на доставку та зберігання, і як наслідок знижується роздрібна ціна. Дропшипінг (дослівно з англійського «dropshipping» - пряма поставка) - це метод управління ланцюжками поставок, при якому продавець не тримає товар на складі, а замість цього передає контакти клієнтів і деталі замовлення посереднику, який, в свою чергу, займається відправкою замовлення безпосередньо покупцеві [7] (рис. 2).

Які ж переваги дропшипінгу для постачальників продукції? Колишні методи роботи змушували підприємця, крім маркетингових завдань, вирішувати різні логістичні проблеми. Потрібно обдзвонити покупців, забрати зі складів постачальників товар, знайти місце для його зберігання, упакувати і передати в службу доставки, при необхідності розібрати повернення. При користуванні послугами дропшипера, покупець буде зосереджений на продажі, просуванні, роботі сайту, розширенні номенклатури товару.

Дропшипінг - це процес, в якому заказ виконується посередником, а товар відправляється покупцю від імені продавця. Переваги дропшипінгу:

1. Мінімізація ризиків. Немає необхідності зберігати товарні запаси або платити постачальнику аванс. Оскільки фрізично та документально товар не належить дропшиперу, не потрібно платити за них та закупати їх оптом. Збиток можливий тільки у вигляді грошей, які потрібно заплатити за реєстрацію домена та хостинг.

2. Доставка. Не потрібно турбуватися щодо доставки та пакування товарів, просто потрібно розмістити заказ на веб-сайті продавця і вони автоматично відправлять товар покупцю. Ризик пошкодження продукту також покривається продавцем.

3. Не потрібно зберігати товари на своїх складах або відкривати місця для роздрібної

\section{Об'єм продажу в електронній торгівлі в світі}

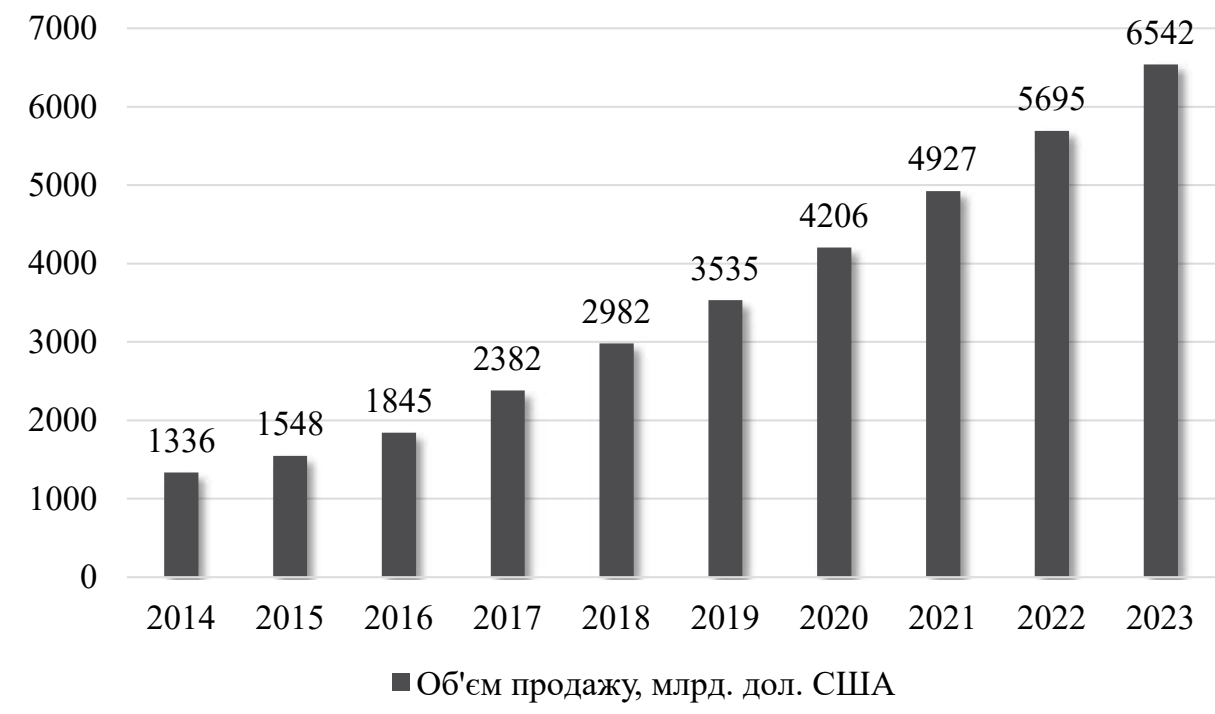

Рис. 1. Електронна торгівля в світі з 2014 р. $з$ прогнозом до 2023 р. Джерело: побудовано за даними The Statistical Portal 


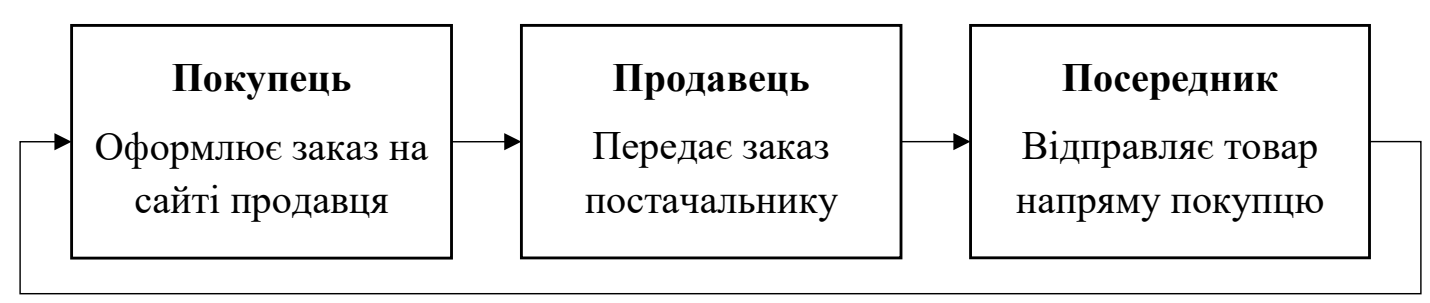

Рис. 2. Схема діяльності системи дропшипінгу

Джерело: складено авторами

торгівлі, потрібен лише веб-сайт, де будуть продаватися товари.

Проблеми в дропшипінгу також присутні, такі як: знайти надійного постачальника, якому можна б було довіряти і співпрацювати на вигідних умовах; відсутність контролю за товарними запасами, велика конкуренція, необхідність певних навичок при веденні бізнесу.

Дропшипінг - явище нове і досконало не досліджене. Через відсутність законодавчо закріпленої категорії, нині дропшипінг розглядається і обліковується як агентська або комісійна діяльність Проте, зважаючи на ріст популярності такого виду діяльності, необхідно врегулювати ії на законодавчому рівні. Адже відсутність нормативної бази призводить до суперечок у бухгалтерському обліку таких операцій.

Слід зазначити, що дропшипінг є напрямом ведення бізнесу, і тому потрібно або реєструватися підприємцем, або відкривати компанію, тобто необхідно враховувати витрати на реєстрацію і в подальшому на податки, також витрати на обслуговування банківського рахунку, бухгалтерське обслуговування та інші необхідні для цього напрямку затрати. Використання такої системи може бути корисно в сучасних умовах фуункціонування малого бізнесу враховуючи тенденції змін в системі його оподаткування [8].

Тож, для того, аби займатися цим видом діяльності, як і в будь-якому іншому, необхідно першочергово розуміти послідовність дій, що представлені на рис. 3.

Перше, що необхідно зробити - вирішити, що саме буде продаватися. Потрібно покладатися не лише на особистий смак та розсуд. Спочатку визначити цільову аудиторію. Дізнатися проблеми потенційних клієнтів і запропонувати їм продукт, який допоможе їм вирішити їх та задовольнити всі потреби. Таким чином ви збільшите цінність пропозиції.

Проаналізувати продукцію, яка буде продаватися, чи приноситиме вона прибуток, які має перспективи. Другий етап - зареєструвати фрізичну особу-підприємця (ФОП) чи компанію, якщо у вас немає такого статусу. Потім, посередник починає пошук постачальників, готових працювати по схемі дропшипінга, знаходить сайт постачальника товарів, ціна якого в рази відрізняється від цін на місцевих ринках при умові, що постачальник продає свої товари поштою і домовляється про умови взаємодії.

Отримавши інорормацію про продукцію, якість товарів та ілюстрації до них, посередник робить пробну закупівлю і обговорює 3 постачальником умови подальшого співробітництва, якщо все влаштовує (гарантії, умови відвантаження та ін.) Продумати всі деталі товару, що складе його майбутню ціну, такі як: вартість доставки, яка буде стягуватися 3 покупців, методи оплати, власна вигода.

Наступний крок - посередник створює сайт в соціальній мережі, копіює або робить особисто опис і зображення товарів постачальника і потім виставляє їх на електронних майданчиках від свого імені, необхідний оригінальний опис товару. Сайт, який підходить для дропшипінгу повинен відповідати багатьом вимогам. У нього повинен бути сучасний дизайн, зрозумілий каталог і зручні картки товарів. У кожної картки повинні бути великі якісні ілюстрації, докладний опис і помітна кнопка «Купити». Також варто подбати про зручність оформлення замовлення: занадто велика кількість кроків, які потрібно пройти і полів, які потрібно заповнити, може стати причиною уходу потенційного клієнта до конкурентів. Також треба подбати про наявність всіх необхідних інтеграцій, які дозволять автоматизувати роботу.

Після створення сайту та просування його в інтернеті, після пошуку потенційних клієнтів, з'являються покупці. Вони купують товари у посередника з відпуском у постачальника. При цьому посередник тільки приймає закази й переводить оплату за мінусом своєї винагороди постачальнику.

Важливим пунктом $€$ момент створення договору. Для цього рекомендується залу- 
Етапи здійснення дропшипінгу

\begin{tabular}{|c|}
\hline Визначення виду діяльності \\
\hline 7 \\
\hline Реєстрація бізнесу \\
\hline$\checkmark$ \\
\hline Заключення договорів з постачальниками \\
\hline I \\
\hline Реклама товару в інтернеті \\
\hline$\checkmark$ \\
\hline Замовлення товару у дропшипера з попередньою оплатою \\
\hline$\checkmark$ \\
\hline Формування замовлення \\
\hline$\checkmark$ \\
\hline $\begin{array}{c}\text { Передача замовлення постачальнику, перерахування попередньої оплати } \\
\text { дропшипером постачальнику }\end{array}$ \\
\hline$\checkmark$ \\
\hline $\begin{array}{c}\text { Виконання замовлення: відправлення товару } \\
\text { постачальником покупцю }\end{array}$ \\
\hline
\end{tabular}

Рис. 3. Схема здійснення дропшипінгу

Джерело: створено авторами

чити професіонального юриста. Крім того, 3 січня 2006 р. Закон України «Про захист прав споживачів» включає положення, що стосуються «договорів, укладених на відстані», тобто договорів, укладених продавцем (виконавцем) зі споживачем, окрім іншого, за допомогою телекомунікаційних та інформаційних мереж (зокрема, Інтернету).

Але, оскільки дропшипінг - явище нове, то в законодавстві спеціально не передбачено договору, що регулює відносини дропшипера і виробника. Тому на практиці можуть бути використані два варіанти: агентський договір і змішаний варіант. Більш детально розглянемо перший варіант. У разі агентського договору, виробник доручає дропшиперу продати його товар. У цьому випадку не виникає ні доходів в частині отриманих від покупця коштів, відповідно до п. 6.2 НП(С)БО 15 «Доходи» [1], ні витрат в частині оплати товарів виробникам, згідно з п. 9.1 НП(С)БО 16 «Витрати» [2]. А визнаватися доходами і витратами дропшипера будуть саме дохід від наданих послуг (агентська/комісійна винагорода) і пов'язані
3 його отриманням витрати, що відображаються в обліку на дату відображення доходів від надання агентських послуг (табл. 1).

Оцінити завершеність операцій $з$ надання послуг на дату балансу можна дотримуючись таких умов:

- можливість достовірної оцінки доходу;

- ймовірність надходження економічних вигід від надання послуг;

До витрат можна буде віднести саме ті витрати, що пов'язані з виконанням операцій дропшипінгу, такі як: комісія банку, винагорода бухгалтеру, консультанту, витрати на канцтовари, програмне забезпечення тощо. Вищезазначене обумовлює наступний порядок відображення операцій дропшипінгу у системи бухгалтерського обліку дропшипера за умови визнання даної діяльності агентською.

Також існує інший варіант офрормлення операцій дропшипінгу, за умови складання змішаного договору (табл. 2). В даному випадку, з позицій дропшипера, за укладеним договором комісії та договоромдоручення 3 постачальником, він зобов'язується прода- 
Облікове відображення операцій дропшипінгу

Таблиця 1

з позиції дропшипера за умови агентської діяльності

\begin{tabular}{|c|c|c|l|}
\hline № & Дт & Кт & \multicolumn{1}{|c|}{ 3міст операції } \\
\hline 1 & 311 & 685 & Надійшли від покупця кошти на придбання товару; \\
\hline 2 & 685 & 377 & Утримано агентську винагороду; \\
\hline 3 & 643 & 641 & Відображення податкових зобов'язань з ПдВ; \\
\hline 4 & 685 & 311 & Перераховано гроші виробникові товару; \\
\hline 5 & 641 & 644 & Відображено податковий кредит; \\
\hline 6 & 377 & 703 & Визнано дохід від наданих агентських послуг; \\
\hline 7 & 703 & 643 & Нараховано ПдВ на суму агентської винагороди; \\
\hline 8 & 903 & $\begin{array}{c}20,22, \\
65,66\end{array}$ & Списано собівартість витрат, пов'язаних з наданням агентських послуг. \\
\hline
\end{tabular}

\section{Джерело: складено автором}

вати його товар, офрормлюючи відносини із покупцями щодо реалізації товарів/продукції за допомогою договору купівлі-продажу.
В даному випадку, 3 позицій дропшипера, за укладеним договором комісії та договором доручення $з$ постачальником, він Облікове відображення операцій дропшипінгу з позицій дропшипера
та постачальника в умовах укладання договорів та доручення

Таблиця 2

\begin{tabular}{|c|c|c|c|}
\hline \multirow[t]{2}{*}{ № } & \multirow[t]{2}{*}{ Зміст господарської операції } & \multicolumn{2}{|c|}{$\begin{array}{c}\text { Кореспонденція } \\
\text { рахунків }\end{array}$} \\
\hline & & Дт & Кт \\
\hline 1 & 2 & 3 & 4 \\
\hline \multicolumn{4}{|c|}{ Облікове відображення операцій дропшипінгу з боку дропшипера: } \\
\hline 1 & Отримано кошти від покупця за товар & 311 & 685 \\
\hline 2 & Нараховано податкові зобов'язання з ПдВ & 643 & 641 \\
\hline 3 & Отримано товар від постачальника & 024 & - \\
\hline 4 & Відображення заборгованість перед постачальником за товар & 685 & 631 \\
\hline 5 & Перераховано кошти постачальнику за товар & 631 & 311 \\
\hline 6 & $\begin{array}{l}\text { Здійснено відправку товару постачальником покупцю (за договором } \\
\text { доручення) }\end{array}$ & - & 024 \\
\hline 7 & Здійснено взаємозалік податкових зобов'язань та податкового кредиту & 644 & 643 \\
\hline 8 & Підписано акт наданих послуг постачальнику & 361 & 703 \\
\hline 9 & Відображено податкове зобов'язання з ПДВ & 703 & 641 \\
\hline 10 & Списано собівартість наданих послуг & 903 & 23 \\
\hline 11 & Отримано кошти від постачальника за надані послуги & 311 & 361 \\
\hline \multicolumn{4}{|c|}{ Облікове відображення операцій дропшипінгу з боку постачальника: } \\
\hline 1 & $\begin{array}{l}\text { Відображено дохід від реалізації дропшипером товарів } \\
\text { постачальника (на дату, яку дропшипер вказує у звіті і на яку } \\
\text { оформлює заборгованість перед постачальником) }\end{array}$ & 361 & 702 \\
\hline 2 & Списано відображені раніше податкові зобов'язання з ПДВ & 702 & 643 \\
\hline 3 & Списано вартість понесених витрат на відправку товару покупцю & 93 & $685 / 311$ \\
\hline 4 & $\begin{array}{l}\text { Списано собівартість реалізованих дропшипером товарів (здійснено } \\
\text { відправку товару покупцю за договором доручення та договором } \\
\text { відправки) }\end{array}$ & 902 & 283 \\
\hline 5 & $\begin{array}{l}\text { Отримано від дропшипера кошти за реалізовані товари } \\
\text { (за вирахуванням нагороди дропшипера) }\end{array}$ & 311 & 361 \\
\hline 6 & Списано на витрати суму винагороди дропшипера & 93 & 685 \\
\hline 7 & Відображено податковий кредит у складі вартості комісійних послуг & 643 & 685 \\
\hline
\end{tabular}


зобов'язується продавати його товар, оформлюючи відносини із клієнтами щодо реалізації за допомогою договору купівлі-продажу.

Висновки. На основі проведеного дослідження треба відмітити, що електронний бізнес вже став сучасним, перспективним напрямом, що має великий попит, у якому економічні агенти не тільки розвивають свій бізнес, але й мають можливість отримати передові знання й профресіональні навики в різних сорерах. Основний висновок, отриманий в результаті дослідження полягає в тому, що бізнес-модель дропшипінг для роздрібної торгівлі $€$ досить новим, перспективним напрямом в умовах розвитку електронної торгівлі, що може бути використано для підприємств малого бізнесу.

Основна характеристика дропшипінгу виходячи з даної роботи:

- нова модель бізнесу та відсутність профресіоналізму;

- відсутність основних постачальників по всій країні;

- високий рівень прибутку від клієнтів;

Вивчивши питання облікового відображення операцій дропшипінгу як актуальної моделі електронної торгівлі, можна здійснити наступні висновки. В першу чергу слід зазначити, що поширення дропшипінгу в Україні та світі обумовлено рядом переваг, що досягають учасники даного процесу. У даному контексті було проаналізовано виділені дослідниками переваги та недоліки дропшипінгу 3 позицій його учасників. Проте незважаючи на невеликі затрати на рекламу, кінцеві витрати в достатній кількості зменшується, ніж при організації звичайної торгівлі, що включає в себе пошуки складського приміщення, закупівлю товарів та ін. Даний спосіб реалізації досить можливий в Україні, так як дропшипер не обмежений в рамках інвестицій, середній заробіток даного виду діяльності залежить, в першу чергу, від правильної організаційної роботи, що включає в себе пошуки постачальників і рекламу, а також від виду товарів, міста, де будуть здійснюватися продажі, від конкурентного середовища, цінової політики та ін. Зрештою, ця структурна система життєздатна, хоча набір елементів, що іiї складають, ще не $є$ високопрофресіоналізованим, що відповідає високому рівню прибутковості кінцевих покупців.

\section{СПИСОК ВИКОРИСТАНИХ ДЖЕРЕЛ:}

1. Наказ Міністерства фрінансів України : Про затвердження Національного положення (стандарту) бухгалтерського обліку 15 «Доходи» від 29.11.1999 р. № 290. Дата оновлення: 09.08.2013. URL: http://zakon2.rada.gov.ua/ laws/show/z0860-99 (дата звернення: 05.05.2021).

2. Наказ Міністерства фрінансів України : Про затвердження Національного положення (стандарту) бухгалтерського обліку 16 «Витрати» від 31.12.1999 р. № 318. Дата оновлення: 09.08.2013. URL: http://zakon3.rada.gov.ua/ laws/show/z0027-00 (дата звернення: 05.05.2021).

3. Зосімов В.Б., Берко О.О. Проблеми та перспективи розвитку електронної торгівлі в Україні. Геометричне моделювання та інфрормаційні технології. 2018. № 1(5). URL: http://mdu.edu.ua/wp-content/uploads/ gmit5-51.pdf (дата звернення: 24.04.2021).

4. Україна в цифрах у 2020 році. Київ : Державна служба статистики України, 2018. 241 с.

5. The Statistical Portal. URL: https://www.statista.com/ (дата звернення: 14.04.2021).

6. Федорчак В. Дропшипінг: переваги та недоліки такої моделі бізнесу. Київ : Маркетинг, 2013. URL: https://webexpert.com.ua/ua/dropshipping-perevagi-tanedoliki (дата звернення: 12.04.2021).

7. Кузьменко Н.В., Онищенко О.В., Циган Р.М. Тенденції змін в системі оподаткування малого бізнесу. Міжнародний науковий журнал «Інтернаука». Серія : «Економічні науки». 2021. № 5. URL: https://doi.org/ 10.25313/2520-2294-2021-5-7287

\section{REFERENCES:}

1. Pro zatverdzhennia Natsionalnoho polozhennia (standartu) bukhhalterskoho obliku 15 «Dokhody»: Nakaz Ministerstva finansiv Ukrainy dated 29.11.1999 No 290. Available at: http://zakon2.rada.gov.ua/laws/show/z0860-99 (accessed 15 May 2021).

2. Nakaz Ministerstva finansiv Ukrainy: Pro zatverdzhennia Natsionalnoho polozhennia (standartu) bukhhalterskoho obliku 16 «Vytraty» vid 31.12.1999 r. No 318. Data onovlennia: 09.08.2013. Available at: http://zakon3.rada.gov.ua/laws/ show/z0027-00 (accessed 15 May 2021).

3. Zosimov V.B., Berko O.O. (2018) Problemy ta perspektyvy rozvytku elektronnoi torhivli v Ukraini [Problems and prospects of e-commerce development in Ukraine]. Heometrychne modeliuvannia ta informatsiini tekhnolohii, no. 1(5). Available at: http://mdu.edu.ua/wp-content/uploads/gmit5-51.pdf (accessed 24 April 2021). 
4. Ukraina v tsyfrakh u 2020 rotsi (2018) [Ukraine in numbers in 2020]. Kyiv: Derzhavna sluzhba statystyky Ukrainy, 241 p. (in Ukrainian)

5. The Statistical Portal. Available at: https://www.statista.com/ (accessed 24 April 2021).

6. Fedorchak V. (2013) Dropshypinh: perevahy ta nedoliky takoi modeli biznesu [Dropshipping: advantages and disadvantages of this business model]. Kyiv: Marketynh. Available at: https://webexpert.com.ua/ua/dropshipping-perevagi-tanedoliki (accessed 12 April 2021).

7. Kuzmenko N.V., Onyshchenko O.V., Tsyhan R.M. (2021) Tendentsii zmin v systemi opodatkuvannia maloho biznesu [Trends in changes in the small business taxation system]. Mizhnarodnyi naukovyi zhurnal «Internauka», Seriia: «Ekonomichni nauky», no. 5. Available at: https://doi.org/10.25313/2520-2294-2021-5-7287 